\title{
HAMBATAN-HAMBATAN YANG DIHADAPI CINA DALAM MELINDUNGI ALIRAN MINYAK BUMI DARI ANCAMAN INDIA
}

\author{
Randy Julio Putra
}

\begin{abstract}
The increasing usage of electricity and transportation also the rapid industrial growth are three factors that cause China's demand on crude oil supply keep increasing. Because of its limited capacity to produce its own oil, China leave with no choice but to become an oil importing country. Middle East is China's biggest oil supplier. The high dependency on Middle East oil supply make China become highly dependent on Malacca Strait. India naval facility in Andaman and Nicobar Islands and its partnership with The United States perceived as a threat to the oil supply that flow through the Malacca Strait. This paper aim is to explore obstacles that China face in protecting its own oil supply from India.
\end{abstract}

Key Words: Crude oil, China, India, Malacca Strait.

\section{Pendahuluan}

Minyak bumi merupakan unsur material yang dibutuhkan negara untuk menjaga pertumbuhan ekonomi dan kesejahteraan sosial masyarakat. Untuk dapat meningkatkan pertumbuhan ekonomi, sebuah negara harus dapat memacu tingkat pertumbuhan industrinya. Untuk melakukan hal tersebut, negara tentu akan membutuhkan sumber daya energi untuk keperluan bahan bakar industri. Minyak bumi merupakan salah satu jenis sumber daya energi yang seringkali digunakan negara sebagai bahan bakar industri. Selain untuk keperluan pertumbuhan industri, negara juga membutuhkan minyak bumi untuk dapat menjaga kesejahteraan sosial masyarakat. Akses terhadap tenaga listrik dan kelancaran kegiatan mobilisasi merupakan beberapa aspek terpenting dari kesejahteraan sosial masyarakat. Negara membutuhkan minyak bumi sebagai bahan bakar untuk pembangkit tenaga listrik dan alat transportasi. 
Secara umum negara berpopulasi besar yang disertai dengan pertumbuhan industri yang pesat cenderung memiliki tingkat permintaan minyak bumi dalam jumlah yang lebih besar dibandingkan negara lainnya. Kondisi ketidakseimbangan antara tingkat permintaan dengan kapasitas produksi minyak bumi menjadi faktor utama yang mendorong negara untuk mengimpor minyak bumi dari negara lain. Ketika ketergantungan terhadap pasokan minyak bumi asing menjadi semakin meningkat, keamanan jalur transportasi minyak bumi pun mulai mendapatkan sorotan khusus dari negara pengimpor (Ji 2007, p.467).

\section{Kondisi Ketergantungan Cina Terhadap Pasokan Minyak Bumi Asing}

Cina merupakan salah satu negara yang memiliki tingkat permintaan minyak bumi yang tinggi. Sedikitnya terdapat tiga faktor yang mengakibatkan permintaan terhadap pasokan minyak bumi terus melambung tinggi. Pertama, tingkat penggunaan tenaga listrik yang besar. Cina merupakan negara dengan populasi terbesar di dunia. Jumlah populasi di negara ini diperkirakan mencapai angka 1,4 milyar orang (Gawdat 2010). Padatnya populasi di negara ini mengakibatkan intensitas penggunaan tenaga listrik pun menjadi semakin besar. Cina menggunakan minyak bumi dalam jumlah yang besar sebagai bahan bakar untuk pembangkit tenaga listrik (Yergin 2006, p.72). Kedua, meningkatnya angka penggunaan alat transportasi. Angka kepemilikan mobil pribadi di Cina yang mengalami peningkatan dari 0,3 mobil per seribu orang di tahun 1985 menjadi 1 mobil per seribu orang pada tahun 2003 (Chong 2007). Ketiga, pesatnya pertumbuhan industri di Cina. Industri bahan kimia merupakan salah satu jenis industri yang paling berkembang pesat di negara ini. Jumlah industri jenis ini bertambah dengan cukup signifikan dari 12.481 di tahun 2002 menjadi 15.172 pada tahun 2004 (Bergsten et al 2008). Industri bahan kimia menggunakan naphta, sejenis bahan baku yang diolah dari minyak bumi dalam jumlah yang besar (Bergsten et al 2008). 
Penggunaan tenaga listrik dalam jumlah besar, meningkatnya penggunaan alat transportasi serta pesatnya pertumbuhan industri bahan kimia merupakan tiga faktor yang mengakibatkan permintaan terhadap pasokan minyak bumi terus meningkat. Terbatasnya kapasitas produksi tambang minyak bumi di Cina mengakibatkan negara ini mengalami kesulitan untuk memenuhi permintaan pasokan minyak bumi untuk kebutuhan domestik (Chong 2007). Cina tidak mempunyai pilihan selain menjadi negara importir minyak bumi untuk mengatasi masalah ketidakseimbangan antara tingkat permintaan dengan keterbatasan kapasitas produksi minyak bumi (Broadstock 2014). Setelah menjadi negara importir, angka net impor minyak bumi Cina terus meningkat setiap tahunnya. Pada periode tahun 2003-2007, angka net impor minyak bumi Cina mengalami peningkatan yang signifikan. Pada tahun 2003, total net impor Cina telah mencapai angka 107,7 juta ton (Wang 2015). Pada tahun 2007, angka net impor meningkat lagi dari 107,7 juta ton menjadi 183,9 juta ton (Wang 2015). Di tahun ini Cina dinobatkan sebagai negara importir minyak bumi terbesar ketiga di dunia setelah Amerika Serikat dan Jepang (Wang 2015). Menurut perkiraan Beijing, tingkat impor minyak bumi akan terus melambung tinggi hingga mencapai angka 240 juta ton pada tahun 2020 mendatang nanti (Ji 2007, p.469).

\section{Selat Malaka dan Keamanan Aliran Minyak Bumi Cina}

Kawasan Timur Tengah, Afrika dan Asia Pasifik merupakan supplier minyak bumi untuk Cina. Pada tahun 2003, Cina telah mengimpor 50,9\% minyak bumi dari Timur Tengah, 24,3\% dari kawasan Afrika, dan 15,2\% dari kawasan Asia Pasifik (Wang 2015). Dari perbandingan tersebut terlihat jelas bahwa kawasan Timur Tengah merupakan supplier utama Cina. Seluruh pasokan minyak bumi dari kawasan Timur Tengah diangkut ke daratan Cina melalui jalur laut. Kapal pengangkut minyak berangkat dari Selat Hormuz menuju Selat Malaka untuk kemudian mencapai daratan utama Cina (Wang 2015).Membawa pasokan minyak bumi melalui jalur laut tidak hanya memakan banyak waktu namun juga sangat berbahaya. 
Selat Malaka merupakan jalur laut yang berperan sebagai gerbang penghubung antara kawasan Timur Tengah dengan daratan Cina. Dikarenakan kawasan Timur Tengah merupakan supplier minyak bumi terbesar bagi Cina, kini Selat Malaka menjadi jalur laut yang bersifat vital bagi keamanan aliran minyak bumi negara ini. Diperkirakan terdapat sekitar 77\% minyak bumi impor Timur Tengah dibawa oleh kapal tanker melalui jalur laut yang sempit dan berbahaya ini (Zhang 2011, p.7613). Sedikitnya terdapat sekitar 10,3 juta barel minyak bumi yang dialirkan melalui Selat Malaka setiap harinya (Lanteigne 2008, p.149). Ketergantungan terhadap aliran minyak bumi Timur Tengah membuat Cina mulai menyoroti kondisi keamanan Selat Malaka. Setiap gangguan atau bahkan yang terburuk blokade, dapat menempatkan keamanan aliran minyak bumi Cina dalam bahaya. Terganggunya aliran tersebut akan berdampak fatal bagi kesejahteraan sosial dan pertumbuhan perekonomian Cina mengingat pasokan minyak bumi berperan sebagai unsur pembangunnya.

Presiden Hujintao menamai kondisi ketergantungan Cina terhadap Selat Malaka sebagai Malacca Dilemma (Ramadhani 2015, p.154). Di satu sisi Selat Malaka berperan penting bagi aktivitas perdagangan minyak bumi antara Cina dengan kawasan Timur Tengah. Namun di sisi lain, ketergantungan terhadap selat ini juga dapat menempatkan keamanan aliran minyak bumi dalam keadaan bahaya. Seluruh minyak impor dari Timur Tengah dibawa kapal tanker melalui Selat Malaka dimana terdapat angkatan militer India disekitar selat ini (Bastos 2014). Dengan fasilitas militernya yang berdekatan dengan Selat Malaka, India menjadi ancaman potensial bagi keamanan aliran minyak bumi Cina.

\section{India sebagai Ancaman Terhadap Keamanan Aliran Minyak Bumi Cina}

India merupakan salah satu negara kuat di kawasan Asia Selatan. Stabilitas aliran minyak bumi, kekuatan persenjataan, kapasitas industri, serta kemakmuran masyarakat India sangat bergantung pada Samudera 
Hindia (Holslag 2010). Terdapat 4 faktor yang menyebabkan ketergantungan tersebut. Pertama, mengalami hal yang serupa dengan Cina, kemajuan perekonomian India membuat permintaan terhadap pasokan minyak bumi mengalami peningkatan (Kaya \& Kilic 2017, p.164). Kondisi ketidakseimbangan antara kapasitas produksi dengan tingkat konsumsi minyak bumi membuat India terpaksa menjadi negara importir minyak bumi (Kaya \& Kilic 2017, p.164). India juga sangat bergantung pada jalur laut dalam melaksanakan aktivitas perdagangan minyak bumi. Sedikitnya terdapat sekitar 80\% minyak bumi diimpor melaui berbgai jalur laut di sepanjang Samudera Hindia (Kaya \& Kilic 2017, p.165). Kedua, tidak hanya ekspor minyak bumi saja, namun seluruh persenjataan serta bahan baku untuk keperluan industri India juga dialirkan melalui jalur ini (Khan 2010, p.107). Ketiga, Samudera Hindia kaya akan sumber daya ikan. Kekayaaan hayati tersebut dimanfaatkan untuk menjaga kesejahteraan ekonomi 16 juta masyarakat India yang bermata pencaharian di bidang perikanan (Holslag 2010).

Dalam rangka menjaga stabilitas aliran minyak bumi, kekuatan persenjataan, kapasitas industri, serta kemakmuran masyarakat India, Samudera Hindia harus terbebas dari berbagai macam ancaman dan dominasi kekuatan asing. Dalam doktrin militer India yang dipublikasikan pada tahun 2004 dikatakan bahwa terdapat beberapa negara berkekuatan besar yang ingin mendominasi kawasan Samudera Hindia (Holslag 2010).Cina merupakan salah satu negara yang dicurigai India sebagai ancaman potensial bagi stabilitas Samudera Hindia (Holslag 2010). Salah satu fitur utama dari doktrin maritim tersebut adalah mengontrol berbagai pulau yang memiliki nilai strategis yang signifikan bagi keamanan India (Khan 2010, p.109). Andaman dan Nicobar merupakan dua pulau strategis yang dapat membantu India untuk memonitori, membatasi, bahkan juga memblokir aktivitas maritim Cina di Samudera Hindia (Berlin 2006, p. 76).

Pulau Andaman dan Nicobar berjarak sekitar $160 \mathrm{~km}$ dari Selat Malaka (Scott 2013, p.498). Selat ini merupakan gerbang masuk ke Samudera Hindia dan juga merupakan jalur laut yang digunakan Cina 
untuk kegiatan perdagangan minyak bumi dengan kawasan Timur Tengah. Untuk mengawasi serta membatasi aktivitas maritim Cina di Samudera Hindia, India membangun berbagai infrastruktur angkatan laut di kedua pulau tersebut (Berlin 2006, p.76). Pada tahun 2005, India mendirikan Far Eastern Naval Command di pelabuhan Blair di kepulauan Andaman dan Nicobar (Scott 2007, p.126). Setelah mendirikan Fart Eastern Naval Command, India kemudian membangun markas unnamed aerial vehicle (UAV) di pelabuhan yang sama (Berlin 2006, p.81). Tidak berhenti sampai disitu saja, India juga berupaya membangun markas kapal selam bersenjata nuklir di pulau Andaman dan Nicobar (Berlin 2006, p.82).

Memperdalam hubungan kerjasama militer dengan Amerika Serikat menjadi salah satu bentuk upaya lain yang dilakukan India untuk memonitori serta membatasi aktivitas maritim Cina di Samudera Hindia. India memilih Amerika Serikat sebagai aliansi karena keduanya sama-sama ingin menjaga stabilitas keamanan kawasan samudera Hindia (Kaya \& Kilic 2017, p.165). Pada tahun 2005, Amerika Serikat memberikan pernyataan bahwa membantu India untuk menjadi negara major power di abad 21 merupakan agenda utamanya di kawasan Asia (Berlin 2006, p.67). Untuk mencapai tujuan tersebut, Amerika Serikat kemudian membentuk sebuah kerangka kerjasama baru yaitu US-India Defense Relationship pada bulan Juni tahun 2005 (Berlin 2006, p.67). Melalui kerangka kerjasama ini, kedua negara melakukan latihan militer bersama serta menjalankan aksi patroli laut rutin di sekitar Selat Malaka (Wojczewski 2016, p.42).

Ketidakseimbangan antara permintaan dan kapasitas produksi minyak bumi mengakibatkan tingkat ketergantungan Cina terhadap Selat Malaka menjadi semakin besar. Kondisi ketergantungan tersebut membuat Cina menjadi sensitif terhadap segala hal yang dapat mengancam aliran minyak bumi yang melalui jalur laut tersebut. India dipersepsikan sebagai ancaman potensial bagi keamanan aliran minyak bumi Cina. Terdapat dua faktor yang membentuk persepsi Cina mengenai hal tersebut. Pertama, fasilitas angkatan laut India di pulau Andaman dan Nicobar memiliki jarak yang sangat dekat dengan Selat Malaka. Fasilitas tersebut memberikan 
India peluang untuk mengeksploitasi kondisi Malacca dilemma ketika Cina dan India terlibat dalam konflik serius. Kedua, hubungan kerjasama antara India dengan Amerika Serikat. Cina memiliki hubungan historis yang kurang baik dengan angkatan laut Amerika Serikat. Pada tahun 1950an, Amerika Serikat pernah memblokade sejumlah jalur laut strategis di Samudera Pasifik (Ji, 2007, p.473). Aksi blokade tersebut mengakibatkan Cina mengalami kerugian materil yang besar. Tidak hanya itu saja, pada tahun 1992, angkatan laut Amerika Serikat juga pernah menginspeksi kapal laut milik Cina secara paksa di Samudera Hindia (Ji, 2007, p.473). Amerika Serikat dinilai sebagai negara yang memiliki intensi agresif untuk melemahkan Cina. Hubungan kerjasama antara India dan Amerika Serikat dalam bentuk kegiatan patroli laut di sekitar Selat Malaka semakin memperkuat persepsi Cina bahwa India adalah negara yang dapat mengancam keamanan aliran minyak bumi Cina. Melalui kerjasamanya dengan Amerika Serikat, India memiliki peluang yang lebih besar untuk mengeksploitasi kondisi Malacca dilemma ketika India terlibat dalam konflik serius dengan Cina. India dapat menggabungkan kekuatan angkatan lautnya dengan angkatan laut Amerika Serikat untuk memutus aliran minyak bumi Cina dengan cara memblokade Selat Malaka. Memutus aliran minyak bumi sama artinya dengan memutuskan pertumbuhan ekonomi dan mengacaukan kesejahteraan sosial masyarakat Cina.

\section{Upaya yang Dilakukan Cina untuk Melindungi Aliran Minyak Bumi dari Ancaman India}

Kekhawatiran terhadap konsekuensi terburuk dari ancaman potensial India tidak akan menjadi kenyataan jika Cina berhasil mengurangi ketergantungannya terhadap Selat Malaka. Dalam rangka mengurangi ketergantungannya terhadap selat tersebut, Cina membangun jalur transportasi energi alternatif di Pakistan dan Myanmar. Alasan mengapa jalur alternatif tersebut dibangun di Pakistan dan Myanmar adalah karena keduanya memiliki hubungan yang dekat dengan Cina (Buszynski 2009, p.75). 


\section{Hambatan-Hambatan yang Dihadapi Cina dalam Melindungi Aliran Minyak Bumi dari Ancaman India}

Pada bulan Maret 2007, Cina memulai proyek pembangunan jalur transportasi energi alternatif di Pakistan (Lanteigne 2008, p.152). Cina membangun jalur pipa minyak bumi yang menghubungkan Gwadar dengan Xinjiang (Ji 2007, p.475). Gwadar dipilih sebagai lokasi pembangunan jalur pipa minyak bumi karena jaraknya hanya sekitar $400 \mathrm{~km}$ saja dari Selat Hormuz (Ji 2007, p.484). Dengan membangun jalur pipa minyak bumi di Gwadar, kapal tanker bisa mengalirkan pasokan minyak bumi dari Timur tengah ke daratan Cina tanpa melalui Selat Malaka. Itu artinya Cina dapat memangkas banyak pengeluaran biaya transportasi karena pengaliran minyak bumi melalui jalur pipa gwadar dapat mengurangi jarak transportasi laut sebanyak lebih dari 4000 nautical miles (Khurana 2008, p.9). Dibalik keuntungan yang dijanjikan, terdapat juga beberapa hal yang dapat menghambat kinerja dari jalur pipa Gwadar. Hambatan yang pertama adalah pembangunan jalur pipa Gwadar yang melewati gunung Kunlun yang terkenal memiliki medan sulit menimbulkan berbagai masalah teknis yang sangat sulit untuk diatasi oleh Cina (Ji 2007, p.475). Hambatan kedua adalah cuaca dingin yang ekstrim di Xinjiang dapat membuat aliran minyak dari Gwadar ke Xinjiang menjadi macet (Lai 2007, p.528). Selain masalah medan dan cuaca, jalur pipa Gwadar-Xinjiang juga menjadi semakin bermasalah karena sangat rawan untuk disabotase oleh nasionalis Baloch (Lai 2007, p.528).

Pembangunan jalur transportasi energi alternatif di Myanmar juga diyakini dapat membantu mengurangi ketergantungan Cina terhadap Selat Malaka. Pada bulan April 2006, negara Myanmar menyetujui proposal pembangunan saluran pipa minyak bumi yang menghubungkan Sittwe/Kyaukphu dengan Kunming di provinsi Yunan (Khurana 2008, p.10). Pada akhir tahun 2007, Cina mulai melaksanakan pembangunan jalur pipa minyak bumi tersebut (Khurana 2008, p.10). Pengaliran minyak bumi melalui jalur pipa ini diperkirakan dapat mereduksi jarak pengiriman 
minyak bumi sebanyak 1820 nautical miles (Khurana 2008, p.10). Dengan kata lain, jalur pipa minyak bumi Myanmar dapat membantu Cina menyelamatkan sebanyak $10 \%$ aliran minyak bumi yang melewati Selat Malaka (Khurana 2008, p.10). Di balik prospeknya yang menjanjikan, terdapat juga beberapa hambatan yang membuat transportasi minyak bumi melalui jalur pipa di Myanmar tidak dapat berjalan dengan optimal. Hambatan yang pertama adalah tidak semua saluran pipa minyak bumi di Myanmar siap untuk digunakan. (Shaofeng 2011, p.610). Hambatan yang kedua adalah saluran pipa minyak Myanmar tidak dapat bertahan untuk waktu yang sangat lama (Shaofeng 2011, p.611).

Melakukan diversifikasi jalur transportasi energi merupakan salah satu bentuk upaya yang cerdas untuk mengamankan aliran minyak bumi Cina dari ancaman India. Untuk dapat mengurangi ketergantungan terhadap Selat Malaka, jalur transportasi energi alternatif ini harus bekerja dengan optimal. Namun sangat disayangkan dibalik prospek yang menjanjikan terdapat beberapa hambatan yang menghalangi efektifitas kinerja dari jalur transportasi energi alternatif di Pakistan dan Myanmar. Medan yang sulit, cuaca dingin, dan ancaman sabotase nasionalis Baloch merupakan beberapa hal yang menghambat efektifitas kinerja jalur transportasi energi di Pakistan. Medan yang sulit dan cuaca dingin merupakan jenis hambatan yang muncul karena faktor alam. Cina tidak bisa melakukan banyak hal untuk mengatasi hambatan tersebut secara efektif. Selain hambatan alam, melindungi jalur transportasi energi dari ancaman nasionalis Baloch juga merupakan satu tugas yang tidak mudah untuk dilakukan.

Berbeda dengan Pakistan, kinerja dari jalur transportasi energi alternatif di Myanmar hanya terganggu oleh masalah teknis yang tidak terlalu berat. Tidak semua saluran pipa minyak bumi di Myanmar siap digunakan dan daya tahannya pun lemah. Dikarenakan hambatannya hanya tidak terlalu berat, Cina memiliki peluang yang besar untuk mengatasinya. 


\section{Kesimpulan}

Cina akan mengalami kesulitan untuk menjaga pertumbuhan ekonomi dan kesejahteraan sosial masyarakatnya tanpa aliran minyak bumi. Oleh karena itu, menjaga keamanan aliran minyak bumi merupakan kepentingan nasional Cina yang bersifat vital. Keterbatasan daya produksi minyak bumi menyebabkan Cina menjadi sangat bergantung pada pasokan minyak bumi dari kawasan Timur Tengah. Ketergantungan terhadap pasokan minyak bumi Timur Tengah membuat Cina harus menghadapi kondisi Malacca dilemma. Kondisi ini melemahkan Cina karena membuat pertumbuhan ekonomi dan kesejahteraan sosial masyarakat Cina menjadi sangat bergantung pada Selat Malaka. Posisi geografis Cina yang berada jauh dari Selat Malaka membatasi ruang gerak Cina untuk mengawasai dan melindungi aliran minyak bumi yang melewati Selat Malaka. Melalui fasilitas angkatan laut di Pulau Andaman dan Nicobar serta hubungan kerjasamanya dengan Amerika Serikat, India dapat mengeksploitasi kondisi Malacca dilemma ketika India terlibat dalam konflik yang serius dengan Cina. Ancaman potensial ini harus diatasi dengan segera mengingat pertumbuhan ekonomi dan kesejahteraan sosial masyarakat Cina sangat bergantung pada Selat Malaka. Ketergantungan terhadap Selat Malaka menjadi kunci dalam masalah ini. Jika Cina bisa mengurangi ketergantungannya terhadap Selat Malaka, maka aliran minyak bumi akan aman dari dari ancaman India.

Melakukan diversifikasi jalur transportasi energi di Pakistan dan Myanmar merupakan langkah yang cerdas untuk mengurangi ketergantungan terhadap Selat Malaka. Namun sangat disayangkan, kinerja dari saluran pipa minyak bumi di kedua negara tersebut terhambat oleh sejumlah faktor. Medan yang sulit, cuaca dingin di Xinjiang serta ancaman dari nasionalis Baloch merupakan faktor-faktor yang menghambat kinerja dari saluran pipa minyak bumi di Pakistan. Ketiganya merupakan jenis hambatan yang sangat sulit untuk diatasai oleh Cina. Oleh karena itu, bisa dikatakan bahwa saluran pipa minyak bumi di Pakistan tidak dapat banyak 
membantu Cina untuk mengurangi ketergantungannya terhadap Selat Malaka. Berbeda dengan Pakistan, kinerja saluran minyak bumi di Myanmar hanya terhambat oleh masalah teknis yang tidak terlalu berat seperti ketidaksiapan pemakaian sebagian saluran pipa dan daya tahan saluran pipa yang lemah. Karena hambatannya tidak terlalu berat, Cina masih memiliki peluang untuk mengatasinya. Dengan membandingkan hambatan dari kinerja saluran pipa di Pakistan dan Myanmar, maka bisa dikatakan bahwa saluran pipa minyak bumi di Myanmar merupakan solusi yang lebih menjanjikan untuk mengurangi ketergantungan Cina terhadap Selat Malaka.

\section{Daftar Pustaka}

Bastos, Maria 2014, 'The Indian Ocean and the Rise of a Multipolar World Order: The Role of China and India', Policy Perspective, vol. 11, no.2, pp. 17-28, JSTOR database.

Berlin, Donald L 2006,'India In The Indian Ocean', Naval War College Review, vol. 59, no.2, diakses tanggal 17 September 2018,

Broadstock, David C 2014, 'Oil and China', dalam Shujie Yao dan Maria Jesus Herrerias Talamantes (ed.), Energy Security and Sustainable Economic Growth in China, Palgrave Macmillan, New York, pp. 132151.

Buszynski, Leszek 2009, 'Emerging Naval Rivalry in East Asia and the Indian Ocean: Implications for Australia', Security Challenges, vol. 5, no.3, diakses tanggal 17 September 2018,

Chong, Xu Yi 2007, 'China's Energy Security',dalam Michael Wesley (ed.), Energy Security in Asia, Routledge, New York, pp. 42-67.

Fred Bergsten, C, Freeman, Charles, Lardy, Nicholas P, Mitchell, Derek J 2008, China's Rise: Challenges and Opportunities, United Book Press, Washington. 
Gawdat, Bahgat 2010, 'China's Energy Security: Challenges and Opportunities', The Journal of Social, Political, and Economic Studies, vol. 35, no.2, pp. 137-166, ProQuest database.

Holslag, Jonathan 2010, China+India Prospect for Peace, Coulmbia University Press, New York.

http:/ / digitalcommons.usnwc.edu/cgi/viewcontent.cgi?article=2017\&conte $\mathrm{nt}=$ nwc-review

http://dx.doi.or/10.1080/01402390.2012.728134

http:/ / www.regionalsecurity.org.au/Resources/Files/vol5no3Buszynski.pdf

https://www.researchgate.net/publication/32113352_Sino-

Indian_Strategic_Rivalry_in_The_Indian_Ocean_Region

Ji, You 2007, 'Dealing with the Malacca Dilemma: China's Effort to Protect its Energy Supply', Strategic Analysis vol. 31, no.3, diakses tanggal 20 September 2018, http://dx.doi.org/10.1080/09700160701415743

Kaya, Taylan Ozgur and Fatih Kilic 2017, 'Sino-Indian Strategic Rivalry in the Indian Ocean Region', The Journal of Humanity and Society vol.7, no.2, diakses tanggal 20 September 2018,

Khurana, Gurpreet S 2008, 'China's 'String of Pearls' in the Indian Ocean and its Security Implications', Strategic Analysis vol. 32, diakses tanggal September 2018, http:/ /dx.doi.org/ 10.1080/09700160801886314

Lai, Hongyi Harry 2007, 'China's Oil Diplomacy: Is it a Global Security threat?', Third World Quarterly, vol. 28, no. 3, diakses tanggal 20 September 2018 , https://www.researchgate.net/publication/242420341_China's_oil_di plomacy_Is_it_a_global_security_threat 
Lanteigne, Marc 2008, 'China's Maritime Security and the Malacca Dilemma', Asian Security, vol. 4, no.2, diakses tanggal 20 September 2018, http: / /dx.doi.org/10.1080/1479985080200655

Raja Mohammad Khan, Colonel Dr 2010, 'Strategic and Regional Implication of Indian Naval Expansion', NDU Journal, diakses tanggal 20 September 2018, https://www.ndu.edu.pk/issra/issra_pub/articles/ndujournal/NDU-Journal-2010/05-Strategic

Ramadhani, Eryan 2015, 'China in the Indian Ocean Region: The Confined far-Seas Operations', India Quarterly, vol.71, no.2, pp.146-159, Sagepub, https://doi.org/10.1177/097492814568616.

Scott, David 2007,'Strategic Imperative of India as an Engineering Player in Pacific Asia', International Studies, vol. 44, no.2, pp. 123-140, Sagepub, DOI:10.1177/002088170704400203.

Scott, David 2013, 'India's Aspirations and Strategy for the Indian OceanSecuring the Waves?', Journal of Strategic Studies vol. 36, no.4, diakses tanggal 21 September 2018,

Shaofeng, Chen 2011, 'Has China's Foreign Energy Quest Enhanced Its Energy Security?', The China Quarterly vol. 207, pp. 600-625, JSTOR database.

Wang, Lirong 2015, 'Sea Lanes and Chinese National Energy Security', Journal of Coastal Research, no.73, pp. 572-576, JSTOR database.

Wojczewski, Thorsten 2016, 'China's rise as a strategic challenge and opportunity: India's China discourse and strategy', India review, vol. 15, no.1, pp. 22-60, DOI: 10.1080/14736489.2015.1092748.

Yergin, Daniel 2006, 'Ensuring Energy Security', Foreign Affairs vol. 85, no.2, diakses tanggal 21 September 2018, JSTOR database. 
Zhang, ZhongXiang 2011, 'China's Energy Security, the Malacca Dilemma and Responses', Energy Policy, vol.39, pp. 7612-7615, ElSEVIER, DOI:10.106/j.enpol.2011.09.033. 